\title{
Resection and reconstruction of the sternum: case report
}

\author{
V. BELTRAM I a nd G. G I D A R O \\ Istituto di Patologia Chirurgica, University of Chieti, Italy
}

\begin{abstract}
Beltrami, V. and Gidaro, G. (1976). Thorax, 31, 350-353. Resection and reconstruction of the sternum: case report. The case history of a 67 -year-old man who underwent a subtotal sternectomy for a tumour of the manubrium and left clavicle is reported. Histological examination revealed a highly undifferentiated metastatic carcinoma: the original tumour was not discovered but the patient was in good condition 10 months after operation. Adequate replacement and stabilization of the chest wall was obtained with autotransplantation of the tibia and muscle flaps.
\end{abstract}

Sternal tumours are relatively uncommon and their malignancy is usually high. They are often metastatic from neoplasms of the lung, breast, kidney or thyroid.

Partial or total resection of the sternum for malignant tumours has been performed up to now in no more than 60 cases. Various methods of reconstruction have been used, for example, mobilization of peripheral tissues, autogenous grafts, and prosthetic devices.

\section{CASE REPORT}

Our patient was a 67-year-old man. In the previous two months he had noticed a small mass in the sternal end of the clavicle; this was hard in consistency and painless and had rapidly increased to reach the size of an egg (Fig. 1). Physical examination revealed that the neoplasm was attached to the clavicle and manubrium sterni. The sedimentation rate was high $(\mathrm{KI}=81)$.

Radiographs showed an osteolytic lesion of the sternal end of the left clavicle and of the manubrium (Fig. 2). Bronchography, barium study, mesenteric angiograms, urography, and isotopic study of the liver and thyroid were non-contributory.

Resection of the manubrium, the inner third of the left clavicle, and the sternal end of both the first two ribs was performed.

Two split tibial grafts, each $8 \mathrm{~cm}$ long, were sutured with steel wire to the resected ends of the first and second ribs in order to close the

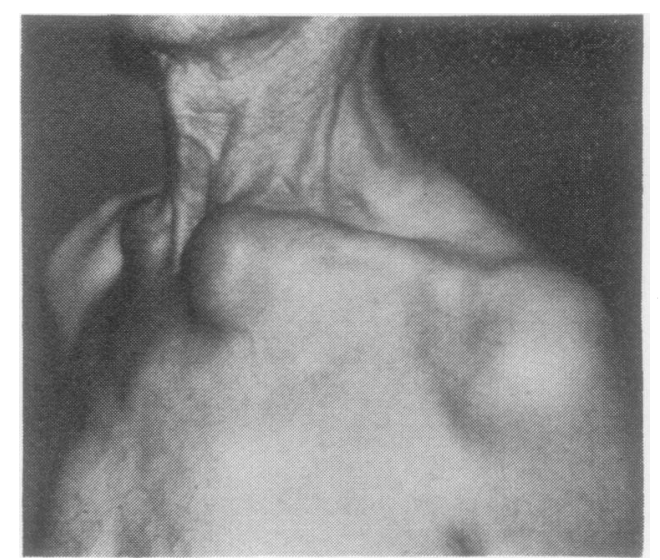

FIG. 1. Shows a mass in the sternal end of the clavicle at the time of admission to hospital.

defect in the anterior chest wall (Fig. 3). The pectoralis muscles and subcutaneus tissues were drawn together in the midline to cover the autoo genous grafts. A drainage tube was placed in the subcutaneous space and the skin was closed.

The patient had an uneventful postoperative course without paradoxical respiration (Fig. 4).

Histological examination revealed a highly un differentiated metastatic carcinoma of uncertaim origin. Further search for the primary tumoug was unsuccessful. The patient is well 10 monthg after the operation. 


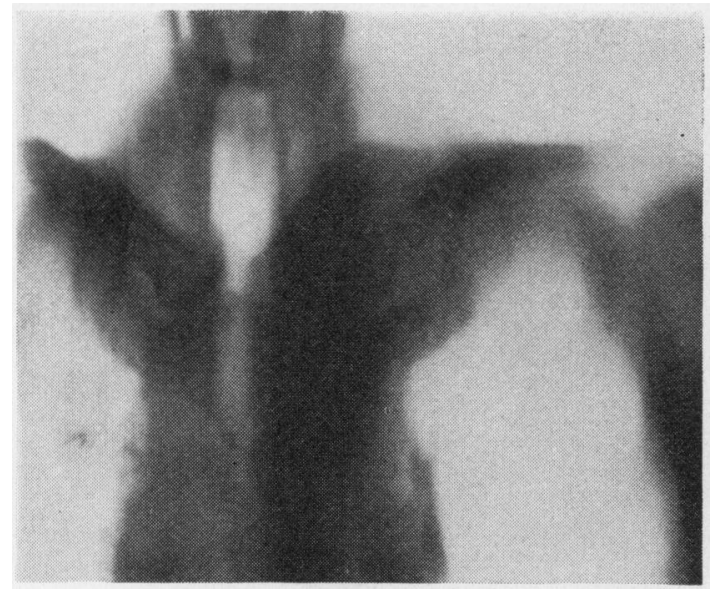

FIG. 2. Osteolysis of the left clavicle and manubrium.

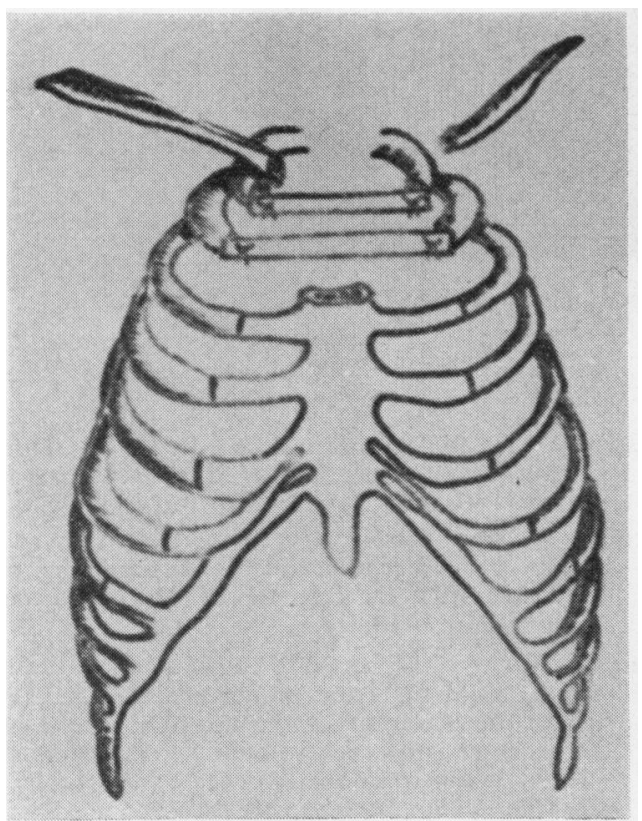

FIG. 3. Two split tibial grafts were sutured to the resected first and second ribs in order to close the chest wall defect.

\section{DISCUSSION}

From 10 to $15 \%$ of neoplasms of the thoracic skeleton are located in the sternum. Benign and primary malignant tumours are unusual; meta- stases from the thyroid, breast, kidney, and lungs form the majority in most reported series.

A palpable mass is the commonest sign; bone pain is present in $10 \%$ of cases. Diagnosis is not easy; metastases in bones may be either osteoplastic or oestolytic, and since primary malignant tumours can behave in the same way, radiographs cannot offer a certain diagnosis. On the other hand, pathological fractures-which may be the first indication of bone metastasis-are unusual in the sternum.

Resection of the sternum, total or partial, poses problems. Chest wall stability, protection of the thoracic organs, and prevention of paradoxical respiration are required. Different methods have been employed to solve these problems: satisfactory results have been obtained both with autogenous grafts and with prosthetic devices (Table). In our patient, split tibial grafts and flaps of muscle were used with a good result.

T A B L E METHODS OF STERNAL RECONSTRUCTION

\begin{tabular}{|c|c|c|}
\hline Reference & $\begin{array}{l}\text { Number } \\
\text { Recorded }\end{array}$ & Method of Repair \\
\hline $\begin{array}{l}\text { Griswold (1947) } \\
\text { Kinsella et al. (1947) } \\
\text { Bisgard and Swenson (1948) } \\
\text { Campbell (1949) } \\
\text { Cotton (1949) } \\
\text { MacManus et al. (1953) }\end{array}$ & $\begin{array}{l}1 \text { partial } \\
2 \text { partial } \\
1 \text { partial } \\
1 \text { partial } \\
1 \text { partial } \\
2 \text { partial }\end{array}$ & $\begin{array}{l}\text { Tantalum prosthesis } \\
\text { Tibia autotransplant (2) } \\
\text { Rib autotransplant } \\
\text { Muscle flaps } \\
\text { Tantalum prosthesis } \\
\text { Fascia lata (1); } \\
\text { muscle flaps (1) }\end{array}$ \\
\hline $\begin{array}{l}\text { Beardsley and } \\
\text { Cavanagh (1950; 1955) } \\
\text { Myre and Kirklin (1956) } \\
\text { Brodin and Linden (1959) }\end{array}$ & $\begin{array}{l}5 \text { partial } \\
1 \text { partial } \\
1 \text { total }\end{array}$ & $\begin{array}{l}\text { Tantalum prosthesis (5) } \\
\text { Muscle flaps } \\
\text { Iliac bone } \\
\text { autotransplant }\end{array}$ \\
\hline $\begin{array}{l}\text { Giraud and Bonneau (1961) } \\
\text { Reboud et al. (1961) }\end{array}$ & $\begin{array}{l}1 \text { partial } \\
1 \text { partial }\end{array}$ & $\begin{array}{l}\text { Nylon prosthesis } \\
\text { Iliac bone } \\
\text { autotransplant }\end{array}$ \\
\hline $\begin{array}{l}\text { Biancalana and } \\
\text { Varola (1962) } \\
\text { Baue (1963) } \\
\text { Nigrisoli (1963) }\end{array}$ & $\begin{array}{l}3 \text { partial } \\
1 \text { total } \\
2 \text { total }\end{array}$ & $\begin{array}{l}\text { Tantalum prosthesis (3) } \\
\text { Marlex prosthesis } \\
\text { Tibia and iliac } \\
\text { autotransplant (2) }\end{array}$ \\
\hline $\begin{array}{l}\text { Kleint (1964) } \\
\text { Grabchenko and } \\
\text { Gaiduk (1965) } \\
\text { Arnold et al. (1966) } \\
\text { Eygelaar (1966) } \\
\text { Siderys } \text { et al. (1966) }\end{array}$ & $\begin{array}{l}1 \text { partial } \\
1 \text { partial } \\
1 \text { total } \\
8 \text { partial } \\
1 \text { partial }\end{array}$ & $\begin{array}{l}\text { Tantalum prosthesis } \\
\text { Acrylic prosthesis } \\
\text { Marlex prosthesis } \\
\text { Marlex prosthesis (8) } \\
\text { Cartilage and }\end{array}$ \\
\hline $\begin{array}{l}\text { Groff and Adkins (1967) } \\
\text { Edland et al. (1969) } \\
\text { Larson et al. (1969) }\end{array}$ & $\begin{array}{l}1 \text { partial } \\
1 \text { partial } \\
1 \text { partial }\end{array}$ & $\begin{array}{l}\text { Stainless steel prosthesis } \\
\text { Marlex prosthesis } \\
\text { Fascia lata+rib } \\
\text { autotransplant }\end{array}$ \\
\hline $\begin{array}{l}\text { Teitelbaum and Bessone } \\
\text { (1969) } \\
\text { Froysaker and Hall (1970) }\end{array}$ & $\begin{array}{l}1 \text { partial } \\
1 \text { total }\end{array}$ & $\begin{array}{l}\text { Muscle flaps } \\
\text { Fascia lata +rib } \\
\text { autotransplant }\end{array}$ \\
\hline $\begin{array}{l}\text { Alonso-Lej and } \\
\text { de Linera (1971) } \\
\text { Calinog et al. (1971) }\end{array}$ & $\begin{array}{l}1 \text { total } \\
2 \text { partial }\end{array}$ & $\begin{array}{l}\text { Acrylic prosthesis } \\
\text { Marlex prosthesis (1); } \\
\text { muscle flaps (1) }\end{array}$ \\
\hline $\begin{array}{l}\text { Peabody (1971) } \\
\text { Echapasse et al. (1972) }\end{array}$ & $\begin{array}{l}1 \text { partial } \\
2 \text { total }\end{array}$ & $\begin{array}{l}\text { Muscle flaps } \\
\text { Rib graft + acrylic (1); } \\
\text { acrylic (1) }\end{array}$ \\
\hline $\begin{array}{l}\text { Mineo et al. (1973) } \\
\text { Vincre (1973) } \\
\text { Zannini (1973) } \\
\text { Beltrami (1974) }\end{array}$ & $\begin{array}{l}1 \text { partial } \\
7 \text { partial } \\
1 \text { partial } \\
1 \text { partial }\end{array}$ & $\begin{array}{l}\text { Iliac bone }+ \text { Silastic } \\
\text { Teflon prosthesis } \\
\text { Muscle flaps } \\
\text { Tibia autotransplant }\end{array}$ \\
\hline
\end{tabular}




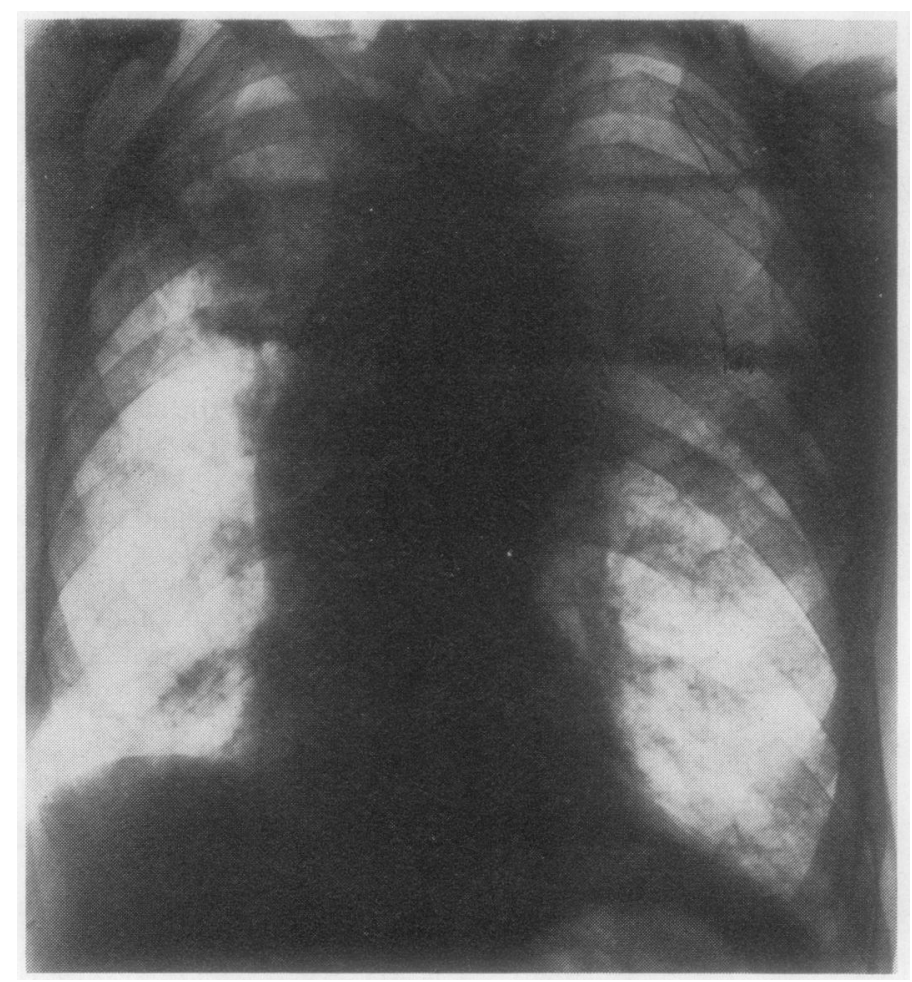

FIG. 4. Chest film five months after operation.

\section{REFERENCES}

Alonso-Lej, F. and Linera, F. A. (1971). Resection of the entire sternum and replacement with acrylic resin. Journal of Thoracic Surgery, 62, 271.

Arnold, H. S., Meese, E. H., d'Amato, N. A., and Maughton, J. S. (1966). Localized Hodgkin's disease presenting as a sternal tumor and treated by total sternectomy. A nnals of Thoracic Surgery, 2, 87.

Baue, A. E. (1963). Total resection of the sternum. Journal of Thoracic and Cardiovascular Surgery, 45, 559.

Beardsley, J. M. (1950). The use of Tantalum plate when resecting large areas of the chest wall. Journal of Thoracic Surgery, 19, 444.

and Cavanagh, C. R. Jr. (1955). Radical excision of malignant chest wall tumors. Journal of Thoracic Surgery, 29, 582.

Beltrami, V. (1974). Chirurgia della parete toracica. Relazione del XIV Congresso della Società Italiana di Chirurgia Toracica, Venezia.

Biancalana, L. and Varola, F. (1962). Traumi del torace. Relazione del VIII Congresso della Società Italiana di Chirurgia Toracica, Venezia.
Bisgard, J. D. and Swenson, S. A., Jr. (1948). Tumors of the sternum. Repcrt of a case with specias operative technic. Archives of Surgery, 56, 570.

Brodin, H. and Linden, K. (1959). Resection of the whole of the sternum and the cartilaginous parts of costae I-IV. A case report. Acta Chirurgica? Scandinavica, 118, 13.

Calinog, T. A., Cushing, W., Merkow, L. P., Mehta V. S., Kent, E., and Magovern, G. J. (1971) Rhabdomyosarcoma of the sternum: the surgicab management and the availability of techniques of sternal reconstruction. Journal of Thoracic and Cardiovascular Surgery, 61, 811.

Campbell, D. A. (1949). Resection of the sternum foe metastatic carcinoma. Annals of Surgery, 129 394.

Cotton, D. M. (1949). As quoted by Cotton, D. M.?.? Paulsen, G. A., and Dykes, Y. (1956).

Paulsen, G. A., and Dykes, Y. (1956): Prothesi following excision of chest wall tumors. Journag of Thoracic Surgery, 31, 45.

Echapasse, H., Gaillard, J., Costagliola, M., Martinel C., Henry, E., and Berthoumieu, F. (1972). Reparation de la paroi thoracique après resection pour tumeur étendue. A propos d'un cas de्e 
résection complète du sternum pour tumeur maligne. Annales de Chirurgie Thoracique et Cardiovasculaire, 11, 445.

Edland, R. W., Muller, T. J., and Johnson, R. O. (1969). Osteogenic sarcoma of the sternum. Wisconsin Medical Journal, 68, 208.

Eygelaar, A. (1966). Resection and reconstruction of the thoracic wall in the treatment of malignant costal and sternal tumours. Archivum Chirurgicum Neerlandicum, 18, 81.

Ferrante, G. and Pastore, V. (1974). Criteri e tecniche della ricostruzione delle lesioni estese della parete toracica. Relazione del XIV Congresso della Società Italiana di Chirurgia Toracica, Venezia.

Froysaker, T. and Hall, K. V. (1970). Reconstruction of the chest wall. Scandinavian Journal of Thoracic and Cardiovascular Surgery, 4, 183.

Giraud, J. and Bonneau, H. (1961). Ostéochondrome du sternum: résection partielle du sternum et plastie au nylon. Marseille Chirurgical, 13, 406.

Grabchenko, I. M. and Gaiduk, P. K. (1965). Alloplasty in subtotal resection of the sternum (Russian). Vestnik Khirurgii, 94(2), 96.

Griswold, R. A. (1947). Osteochondrosarcoma of the sternum: use of Tantalum plate as a prosthesis. Archives of Surgery, 55, 681.

Groff, D. B. and Adkins, P. C. (1967). Chest wall tumors. Annals of Thoracic Surgery, 4, 260.

Kinsella, T. J., White, S. M., and Koucky, R. W. (1947). Two unusual tumours of the sternum. Journal of Thoracic Surgery, 16, 640.

Kleint, Z. (1964). Riesiges rezidivierendes Chondrcsarkom des Brustbeines. Zentralblatt für Chirurgie, 89, 1096.

Larson, R. E., Lick, L. C., and Maxeiner, S. R. Jr. (1969). Technique for chest wall reconstruction following resection of sternal chondrosarcoma. Archives of Surgery, 98, 668.
MacManus, J. E., McCormick, R. C., and Fecher, M. P. (1953). Problems in the management of anterior chest wall tumors. Surgery, 34, 245.

Mineo, T. C., Piccolo, A., and Ricci, C. (1973). Partial resection and reconstruction of the sternum (a case of solitary plasmacytoma). Surgery in Italy, $3,57$.

Myre, T. T. and Kirklin, J. W. (1956). Resection of tumours of the sternum. Annals of Surgery, 144, 1023.

Nigrisoli, P. (1963). Sul trattamento chirurgico dei tumori dello sterno. Minerva Ortopedica, 14, 592.

Peabody, C. N. (1971). Chondrosarcoma of sternum: report of a six year survival. Journal of Thoracic and Cardiovascular Surgery, 61, 636.

Reboud, E., Aubrespy, P., and Castelain, P. (1961). Résection partielle du sternum: sur une solution du problème du comblement de la parte de substance. Marseille Chirurgical, 13, 408.

Siderys, H., Pittman, J. N., and Pontius, E. E. (1966). Autogenous cartilage for repair of defect after sternal resection for enchondroma. Annals of Thoracic Surgery, 2, 442.

Teitelbaum, S. L. and Bessone, L. (1969). Resection of a large chondromyxoid fibroma of the sternum: report of the first case and review of the literature. Journal of Thoracic and Cardiovascular Surgery, 57, 333.

Vincre, G. (1973). Personal communication.

Zannini, G. (1973). As quoted by Ferrante and Pastore (1974).

Requests for reprints tc: Professor V. Beltrami, Istituto di Patologia Chirurgica, University of Chieti, School of Medicine, Italy. 